\title{
Research on Tourism Market Access in China Li Zhen
}

\author{
Qingdao Technical College,Qingdao 266000
}

\begin{abstract}
Tourism service trade plays an important role in the development of national development. It is inconsistent with rapid development of tourism service trade that the researches about tourism service trade falls behind the development requirements of tourism. Especially tourism market access is a complicated topic. From the concept of market access and policies of tourism market access, the paper analyzes the status and limitations of tourism market access in our country.
\end{abstract}

Key words: tourism service trade, market access, general agreement of service trade

\section{INTRODUCTION}

The principles of GATS relating to service trade relates to the restraint of tourism service trade. The principles include service trade transparency principle, progressive liberalization principle differentiating from trade in goods, most-favored-nation treatment principle, more engaged principle of developing countries, restriction and prohibition principle of service trade and service provision permission principle. Market access and national treatment of member states are the concrete manifestation of the above principles. Market access is the condition determining market access, and national treatment is the position after entering market. Market access is prerequisite of national treatment. If it can't enter the market, treatment is impossible, and the provision of national treatment makes no sense, and the access is difficult to be maintained. National treatment is the guarantee of market access. So the application of national treatment is after achieving market admission. Market access negotiation determines if member countries open financial service market, and the commitment of national treatment affects the degree of member states opening market. The boundary between them is definite, and both of them play important role in the liberalization of international service trade. The paper analyzes the status of market access of tourism service trade and proposes solutions.

Since the 1970s, Chinese tourism ranks top of service industry in the opening area and scope. Compared with other countries, the opening-up degree of tourism market in China is not enough, which means that the opening up of tourism service is only limited in tourism hotel industry, the opening

up of travel agency is limited, the core business is not open, and tourist guide service is not open any more.

\section{LIMITATIONS OF TOURISM MARKET ADMISSION IN CHINA}

The economy in China is in the process of transition. Based on the investigation about tourism service trade market access in China, and combined with the existing researches and the status of government regulation, the paper proposes that tourism service trade market access has the following problems.

\section{A. Policy constraint of capital access}

For China which is not developed and needs to promote economic development by the participation of nonpublic enterprise, too high capital access hinders the expansion of tourism service and the formation of full competition environment, which not only can't ensure that the manager must make profit, makes deposition of funds, and increases the cost of enterprise operation, but also hinders small enterprises or individuals to enter travel agency industry to seize the development opportunities. And it can't fully play the role of market competition mechanism to promote the marketization of travel agency industry and enhance comprehensive competitiveness of enterprises. The survival and development of enterprises don't depend on registered capital.

\section{B. Policy constraint of management business}

The opening up of outbound travel business becomes a focus, which forms multiple games of government, Chinese travel services and foreign-capital travel agency. Firstly, according to the existing regulations, various measures are taken to strengthen international tourism administrative departments to maintain the authority. Secondly, Chinese travel services make every attempt to protect the vested interest and increase the investment of human and financial resources. And they even make profits by transferring brands. Thirdly, the foreign-capital and joint-venture tourism enterprises without the qualification make plans to seek countermeasures. With the help of special resources, some enterprise takes other measures to organize various commercial tourism, special tourism and high-end travel activities. More enterprises take the method of participation.

\section{Policy constraint of personnel access}

It is different from the development of industries consuming natural resources that the development of service industry depends on talents. While formulating market access standards, tourism service industry strictly limits the nationality of practitioner. For example, Tour Guide Management Regulations provides that the citizen of PRC 
with the educational background of senior high school and secondary specialized school, and the required basic knowledge and language competence can participate in tour guide qualification examination, which means that tour guide market is not completely open to foreign citizens. It is difficult for the undeveloped regions lacking of talents, which forces the enterprises to achieve the qualification with the help of taking a temporary post. But the personnel make no contributions to promote the enterprise level, and personnel restriction can't play the expected role.

\section{CONSTRAINT MOTIVATION OF TOURISM MARKET ACCESS IN CHINA}

The solution of tourism market access is established on the basis of national competitiveness and bargaining power of tourism service trade in our country. So it is fundamental to solve the problems of tourism market access and promote internal competiveness of tourism. So it is the direction of solving problems to determine correct foreign policies. The opinions about value orientation of tourism market access in our country are as follows.

\section{A. Pursuing native economic interest}

All countries do their best to pursue the native economic interest, which is the objective in the process of international economic intercourse and international economic integration. Just like tariff concession and non-tariff barrier of merchandise trade negotiation, market access is an important content of service trade negotiation in various countries. In the field of service trade, developed countries have incomparable advantages compared with developing countries. Market access is concrete manifestation of service trade liberalization, which means that the home market is open to service industry in foreign countries such as allowing free entry of foreign insurance, banks and electrical communication. It makes the modern service market of developing countries face stronger competition of service field in foreign countries and receives great impact, which is evident in travel service industry. Opening up makes the competition of native tourism market more fierce, and the local tourism enterprises seize the domestic tourism market and segment market share with foreign-capital tourism enterprises, which not only makes the local tourism enterprise business lose, reduces market share and reduce profit level, but also weakens profitability and market competitiveness of local tourism enterprises. Foreign-capital tourism enterprises have a long history, and forms abundant economic strength and rich capital source in the process of development and accumulation. And they have advanced management idea, operation mechanism, financial management technique, investment skill, market skill, and multi-function, omni-directional and high-efficient service means. Therefore, great competition not only increases the cost and reduces economic efficiency, but also reduces return on assets and return ratio, which increases survival pressure of national tourism.

\section{B. Developing national economy}

The development of national economy is very important for a country, and developing the national economy is the primary task of a country. Therefore, in international economic intercourse, the government firstly needs to consider if there is need to develop the national economy. The value orientation of developing national economy exists in developing countries, which plays an important role in going against economic control of other countries and maintaining state sovereignty. But the value orientation has many disadvantages.

Firstly, it is not good for cultivating strategic vision of international development of a country. It only aims at the present economic benefit, which limits the long-term development.

Secondly, the opinion is contrary to the tendency of economic globalization.

Thirdly, the opinion makes the market access expand and complicated in international economic intercourse. Any country has its own national economy. Protecting and developing national economy makes conflicts. And each country can't bear the competition, which makes it difficult to solve market access problems.

\section{Ensuring economic security}

The opinion considers that with the increase of openingup degree in our country, the economy in our country is integrating into world economic development. While promoting domestic development, opening up increases the risk and indetermination. On one hand, international situation has new changes. World multi-polarization and economic globalization develops hardly, the synthetic power competition is increasingly fierce and the contradictions are complicated. On the other hand, our country still faces the pressure of developed countries in economy and science and technology. The dependence degree of foreign trade in our country is very high, and foreign capital occupies considerable proportion of investment and industrial output value.

The historical experiences and lessons have proved that lagging behind leaves one vulnerable to attacks. And the backward of economic development is the most important manifestation in a country. Whatever measures are taken by undeveloped countries or regions to protect the national economy, the safety can't be improved, and it may lose the opportunities of development. Long-term insecurity finally threatens and can't play the role of protecting national security.

\section{Protecting and developing infant industries}

Theory of Protecting Infant Industry has become a theory of many scholars pursuing that the tourism market in China should take protection measures. The content of the theory is as follows. When an emerging industry of a country is in the original period of the optimal scale, it can't stand the foreign competition. Taking protection measures not only can improve the competiveness and have comparative advantages, but also can make contributions to national 
economic development. It is mainly implemented by applying tariff protection.

The development of new industries needs cultivation. The tourism service trade in China has become the pillar industry of national economy, which means that compared with other service trade, the development is matured, and protection can't be the basis of tourism market access in China. Market economy is cruel. Any industry not only is the result of competition, but also is the beginning of the competition from production to development. Artificially cultivating and supporting emerging industries not only can't make the market judge if there is necessary to develop, but also lose internal power and external pressure of selfdevelopment.

\section{INFLUENCE OF MARKET ACCESS LIMITATION ON TOURISM INDUSTRY IN CHINA}

The tourism service industry in our country has been influenced by national high protection for a long time. Operating domestic tourism business lacks of various facilities and qualified personnel, which makes service quality low and quality of tour guides worse.

\section{A. Travel agency lacks of internal development power}

Travel agency is the industry with the most protection in tourism. The enterprises and tourism administration departments strengthen the particularity of the industry, emphasize the protection and support of the special industry and don't implement complete competition and free open, which makes the industry lack of internal development power.

The market mechanism of tourism industry is not healthy, and the present travel agencies have common and unqualified contracted management, travel agency industry expands rapidly. Some competent departments don't fully play the macro-control role, which increases the competition of travel agency industry. Under pressure of competition and the drive of benefit, many travel agencies only focus on customer orientation and ignore cost orientation. And price cutting is the primary means to sell products, which makes little difference between selling price and purchase price. In order to ensure necessary group profit, the travel agencies need to cancel the salary of tour guides, reduce reception standards, and even indulge the tour guides to take the guests to shop for achieving expensive shopping bill.

\section{B. Tourism service level and service quality is low}

Low tourism service level and service quality is one of the influences of long-term national protection on tourism service industry in China. Because there is no external competitor, the domestic market is not regular, and the service quality is low. While holiday travel index creates the record, there are many complaints about service quality.

\section{Establishment of tourism talents can't keep pace with the requirements of practical development}

The other evident influence of market access limitation on tourism industry in China is that domestic enterprises operating tourism business lack of professional talents, especially the quality of tour guides can't achieve national level.

As a part of tourism products, selling products to tourists is the most sensitive for the quality of tourism service products. Unfortunately, while tourism industry in China develops rapidly, the service quality of tour guides is low, which becomes the bottleneck of development of tourism industry.

\section{CONCLUSIONS}

The tourism service industry in our country has been influenced by national protection for a long time. Operating tourism business lacks of various facilities and professional talents, which makes service quality low and quality of tour guides worse. For management, it is common that tourism commodities are sold in hotels, entertainment places and scenic spots. In order to improve the quality of tourism industry and services, macro-management should be enhanced, and the quality of enterprises and personnel should be improved. Especially the state-owned tourism enterprises firstly need to convert operation mechanism and implement separation of enterprise from administration. And the enterprises push into the market, and cancel the privilege and protection, which not only makes the enterprises really become the self-sustaining operator, but also improves the ability participating in international competition. According to international practice and market requirements, the enterprises should organize production and operation activities to promote tourism enterprises to improve service quality.

\section{REFERENCES:}

[1] Yan Huili, Xiong Hao, Analysis on batch and maximum capacity of access in scenic spots [J], Tourism Journal, 2013,04:83-87.

[2] Song Zhenchun, Wang Yunjiao, Thought of access system and tour guide management system [J], Tourism Journal, 2013,07:57-63.

[3] Liu Aifu, Observation on strict access system and healthy management system of tour guides [J], Tourism Journal, 2011,05:62-67.

[4] Guo Zonghai, Functions of government in the development of tourism industry in China [J], Social Scientist,2010,12:92-95.

[5] Zeng Lu, Research on legal problems of self-driving tour [J], Journal of Leshan Teachers College, 2013,03:92-97+102.

[6] Mo Wanyou, Observation on market access and supervision of groupbuying websites [J], Consumption Economy, 2013,01:56-60.

[7] $\mathrm{Li} \mathrm{Yu}$, Specification and management of translation market of characteristic culture tourism in Anhui [J], Journal of Tongling College, 2013,01:94-97. 